\title{
Review of Kevin Tavin, Gila Kolb, and Juuso Tervo (Eds.). (2021). Post-digital, Post-Internet Art and Education: the Future Is All-Over
}

\section{Cham: Palgrave Macmillan. 315 pp. ISBN 9783030737696 (E-Book)}

\author{
Julia Mañero ${ }^{1}$
}

Accepted: 15 December 2021 / Published online: 24 January 2022

(c) The Author(s), under exclusive licence to Springer Nature Switzerland AG 2021

Keywords Postdigital $\cdot$ Arts education $\cdot$ Post-internet $\cdot$ Future studies $\cdot$ Critical theory $\cdot$ Aesthetics $\cdot$ Covid-19

\section{Art Education for an Uncertain Future}

Post-digital, Post-Internet Art and Education: the Future Is All-Over (Tavin et al. 2021) was written at the beginning of 2021. As I write this review at the end of the year, how many political, social, economic, and technological changes have taken place since the book was published? And what more has happened until this moment in which you are reading this review?

Software and hardware upgrades, technological advances, and their new affordances are part and parcel of our present conjuncture. But these developments are now old news. Technological change is no longer disruptive; it is regular, constant, and chaotic. These lines recognize ephemerality of technological change and signal the postdigital condition (Jandrić et al. 2018), which is a concept that lies in the heart of Postdigital Science and Education journal.

The postdigital condition is also in the core of Post-digital, Post-Internet Art and Education: the Future Is All-Over (Tavin et al. 2021). The book adds an important dimension to its understanding, exploring intersections between the postdigital condition, art, and education, claiming the importance of art education and its role in transforming our postdigital reality. These intersections are explored from the position of intersubjectivity, in an exercise of collective intercreation, from multiple places and experiences. A total of nineteen authors are gathered in this book with a common objective: to explore, and make visible, the new movement defined as 'post-Internet art education'.

Julia Mañero

juliamanero@us.es

1 University of Sevilla, Sevilla, Spain 
The approach to the three fundamental concepts and their intersections postdigital, art, and education — is clear, concise, and, above all, pedagogical. The authors examine the Internet as an encounter that includes, but is not limited to, technology, bodies, and materials. As the Internet evolves, so do ways of being (post)-human and being in society. The authors explore the interplay between this encounter and the praxis of education. In words of Freire (1970), education is always political; in many cases, digital education exacerbates the dichotomy between subjects rather than proposes a critical point of view (Farag et al. 2021).

Many other authors have approached digital education from a post-human and postdigital - and therefore critical and political — point of view (see Bayne 2015; Gourlay and Oliver 2018; Knox 2016). Yet authors in Post-digital, Post-Internet Art and Education: the Future Is All-Over (Tavin et al. 2021) bring together many questions that invite reflection on what is to be done about educational processes in general and art education in particular. Thus, this book's insights regarding network configurations, data structures, and algorithms need to be added to well-established approaches in arts education such as Ana Mae Barbosa's 'triangular approach' (2021). Importantly, the authors encompass contemporary artworks that play with dichotomies, explore hybrid spaces, and serve as arenas for critique and reflection on our postdigital condition.

The three concepts are deeply developed throughout the book, converging in what we could call postdigital art education or, following the editors' words, 'postInternet art education'. The editors freely admit that their collection is limited to the context of the Global North, and so they refuse to uniformize or colonize the discourse. Hence, the reader will find different ways of spelling 'postdigital' or 'post-Internet'. This diversity in the use of terms, definitions, and practices signals the recognition of an uncertain and unpredictable future. That is exactly the world that art education faces: uncertain, hybrid, and constantly changing.

\section{How the Global Pandemic Challenged Art Education}

Before the Covid-19 pandemic, humanism used to be the dominant paradigm. The absence of posthumanist visions, particularly in education, led to a widespread denial of online art education (Tavin et al. 2021). However, since the beginning of the pandemic, education faces a rapidly growing need to collect and remix information, share resources, and collaborate in creative and intersubjective ways (see Berners-Lee 2000; see also Jandrić et al. 2020). These trends existed before the pandemic, but now, they have accelerated and brought along unprecedented solidarity (Mañero 2020). All of this strongly impacts art education.

Education in digital environments is synonymous with audio-visually rich environments, interactive contexts with multiple possibilities for co-creation, and social networking services where experiences can be shared, people can connect, and quality art education can be claimed (Tavin et al. 2021). The book gathers several examples of artistic practices in digital learning contexts, encouraging readers to think about arts education from different perspectives, and inviting us to unlearn in order to re-think art education differently. In these examples, digital arts education is not 
the second best but special and different, because it involves the body and other material factors (see Bayne et al. 2020; MacKenzie at al. 2021). On that basis, Tavin et al. (2021) provide a global and pedagogical overview of art education that raises an understanding of where we have come from and uses this understanding to help us choose where we are going.

In the first section, 'How Did We Get Here: Historical, Theoretical, Critical, and Future Oriented Perspectives on Post-digital, Post-Internet Art and Education', authors offer theoretical, historical, and future-oriented perspectives on the main concepts. Chapters in this section reflect how digital and post-Internet cultures raise new possibilities for art education (Klein 2021). Sweeny (2021: 45) names some artists and educators who actively subvert the field of art education in utopian and dystopian manners and suggests that '[a] comparison of these two different systems might offer art educators opportunities to rethink practices that have been virtually unaffected by decentralization'. We must bear in mind, as jagodzinski (2021) points out, that the image dominates the screens and interfaces. The concept of image is analysed in more depth by Schütze (2021), who argues that art educators must be experts in the image and its relationships, structure, and meanings. Last, Knochel (2021) critically exposes the problems of freedom of expression and creativity in teaching and creative processes in hybrid spaces.

The second section, 'Why Is This Important for Art Education? Transdisciplinary Networks, Research, and Subjectivities of the Post-digital and Post-Internet', discusses ways in which issues presented in the first section challenge art education. Rousseau and Sternfeld (2021) argue that education is a public right and cannot be relegated to corporations. Therefore, it is important to analyse the economic and political trade-offs implicit in, for example, the use of technology. Perhaps the most suggestive is authors' reflection on how collective means of production can emerge in a postdigital society.

The debate around new educational approaches resurfaces in Meyers' (2021) reflection on theories such as posthumanism and actor-network theory (ANT). Meyer believes that it is necessary to think about what a 'subject' is, and arts education has a lot to offer in this matter. Exploring the theme of subjectivity and identity, Kommos (2021) considers how technology and digital devices change the way we relate to each other, how we lose our privacy, and how we generate new identities. On that basis, Kommos argues that it is necessary to approach these issues simultaneously from an artistic and educational angle. In the same spirit, Kolb (2021) analyses the concept of the body in relation to digital education. She stresses that digital education materializes in the body and offers five illustrative examples.

In the realm of aesthetics, Zahn (2021) discusses what he calls the 'media-critical practice' and analyses new concepts to related to the critique of the human and the non-human. In particular, Zahn devotes considerable attention to subverting established norms and transforming the context. The image and its aesthetics is what Schmidt (2021) works on with his students, recovering Hito Steyerl's (2009) concept of 'poor image'. Zahn (2021) recovers the concept in images that we consume on a daily basis and uses it as a pedagogical resource in the classroom.

The third section, 'How Can We Create Educational Futures? Classroom and Pedagogical Practices Examples of Post-Digital and Post-Internet Art Education', 
showcases a series of pedagogical practices that help the reader to consider possible artistic educational actions in a postdigital terrain. Hahn (2021) focuses on new materialities by analysing materiality in the relationship between the artist and the final artefact. Smith (2021) brings anti-colonial and anti-racist lenses into the debate and claims that digital arts education curricula presented under a non-global-north viewpoint can be transformative for students. Grünwald (2021) recovers Freire's ideas such as the concept of 'banking education' and claims that it is difficult to develop transformative action when teachers are afraid to step out of their comfort zone.

In her proposal for creative coding in a university context, Dufva (2021) takes a feminist approach to examine the possibilities of combining creativity and coding. Her chapter encourages readers to reach further and examine creative coding in the context of transhackfeminism. The book closes with Dufva's (2021) pedagogical proposal based on generating fiction on Instagram. She argues that learning takes place in these creative processes, where students learn the workings of algorithms and social networking services.

\section{The Uncertain (But Promising) Future of Art Education}

Post-digital, Post-Internet Art and Education: the Future Is All-Over (Tavin et al. 2021) is highly recommended to those interested in recognising their postdigital status and seeking new opportunities for art education. Future may be uncertain, but for art education, this uncertainty seems very promising. Current developments in arts and education, combined with the critical dimension of postdigitality, have the capacity to raise a new generation of critical human beings with the ability to look at and inhabit a visual and technological world. Perhaps more importantly, art education has the capacity to create new and different worlds.

Editors and authors of Post-digital, Post-Internet Art and Education: the Future Is All-Over (Tavin et al. 2021) send a strong message that change is possible. The book is an outstanding source of ideas that push us out of our comfort zones and challenge us to think differently about digital art education. This is a collectively written book, open to multiple interpretations and full of varied experiences, and bound to inspire its readers in thinking about and creating their own art education praxis.

\section{References}

Barbosa, A. M. (2021). Images in Teaching and Research since the (Post) Covid-19 Era. Plenary lecture at the International Congress of Arts, Education and Postdigitality. Sevilla: University of Sevilla.

Bayne, S. (2015). What's the matter with 'technology enhanced learning'? Learning, Media and Technology, 40(1), 5-20. https://doi.org/10.1080/17439884.2014.915851.

Bayne, S., Evans, P., Ewins, R., Knox, J., Lamb, J., Mcleod, H., et al. (2020). The Manifesto for Teaching Online. Cambridge, MA: MIT Press.

Berners-Lee, T. (1999). Weaving the web: The original design and ultimate destiny of the World Wide Web. New York: Harper Collins. 
Dufva, T. S. (2021). Creative Coding as Compost(ing). In K. Tavin, G. Kolb, \& J. Tervo (Eds.), PostDigital, Post-Internet Art and Education: The Future is All-Over (pp. 269-283). Cham: Palgrave Macmillan. https://doi.org/10.1007/978-3-030-73770-2_16.

Farag, A., Greeley, L., \& Swindell, A. (2021). Freire 2.0: Pedagogy of the digitally oppressed. Educational Philosophy and Theory, https://doi.org/10.1080/00131857.2021.2010541.

Freire, P. (1970). Pedagogy of the oppressed. New York: Continuum.

Gourlay, L., \& Oliver, M. (2018). Student Engagement in the Digital University. Sociomaterial Assemblages. London: Routledge.

Grünwald, J. G. (2021). Embracing Doubt: Teaching in a Post-digital Age. In K. Tavin, G. Kolb, \& J. Tervo (Eds.), Post-Digital, Post-Internet Art and Education: The Future is All-Over (pp. 257-267). Cham: Palgrave Macmillan. https://doi.org/10.1007/978-3-030-73770-2_15.

Hahn, A. (2021). Educating Things: Art Education Beyond the Individual in the Post-Digital. In K. Tavin, G. Kolb, \& J. Tervo (Eds.), Post-Digital, Post-Internet Art and Education: The Future is All-Over (pp. 225-238). Cham: Palgrave Macmillan. https://doi.org/10.1007/978-3-030-73770-2_13.

jagodzinski, j. (2021). A Meditation on the Post-digital and Post-internet Condition: Screen Culture, Digitalization, and Networked Art. In K. Tavin, G. Kolb, \& J. Tervo (Eds.), Post-Digital, Post-Internet Art and Education: The Future is All-Over (pp. 61-80). Cham: Palgrave Macmillan. https://doi.org/ 10.1007/978-3-030-73770-2_4.

Jandrić, P., Hayes, D., Truelove, I., Levinson, P., Mayo, P., Ryberg, T., Monzó, L. D., Allen, Q., Stewart, P. A., Carr, P. R., Jackson, L., Bridges, S., Escaño, C., Grauslund, D., Mañero, J., Lukoko, H. O., Bryant, P., Fuentes Martinez, A., Gibbons, A., Sturm, S., Rose, J., Chuma, M. M., Biličić, E., Pfohl, S., Gustafsson, U., Arantes, J. A., Ford, D. R., Kihwele, J. E., Mozelius, P., Suoranta, J., Jurjević, L., Jurčević, M., Steketee, A., Irwin, J., White, E. J., Davidsen, J., Jaldemark, J., Abegglen, S., Burns, T., Sinfield, S., Kirylo, J. D., Batarelo Kokić, I., Stewart, G. T., Rikowski, G., Lisberg Christensen, L., Arndt, S., Pyyhtinen, O., Reitz, C., Lodahl, M., Humble, N., Buchanan, R., Forster, D. J., Kishore, P., Ozoliňš, J., Sharma, N., Urvashi, S., Nejad, H. G., Hood, N., Tesar, M., Wang, Y., Wright, J., Brown, J. B., Prinsloo, P., Kaur, K., Mukherjee, M., Novak, R., Shukla, R., Hollings, S., Konnerup, U., Mallya, M., Olorundare, A., Achieng-Evensen, C., Philip, A.P., Hazzan, M. K., Stockbridge, K., Komolafe, B. F., Bolanle, O. F., Hogan, M., Redder, B., Sattarzadeh, S. D., Jopling, M., SooHoo, S., Devine, N., \& Hayes, S. (2020). Teaching in The Age of Covid-19. Postdigital Science and Education, 2(3), 1069-1230. https://doi.org/10.1007/s42438-020-00169-6.

Jandrić, P., Knox, J., Besley, T., Ryberg, T., Suoranta, J., \& Hayes, S. (2018). Postdigital Science and Education. Educational Philosophy and Theory, 50(10), 893-899. https://doi.org/10.1080/ 00131857.2018.1454000.

Klein, K. (2021). Post-digital, Post-internet: Propositions for Art Education in the Context of Digital Cultures. In K. Tavin, G. Kolb, \& J. Tervo (Eds.), Post-Digital, Post-Internet Art and Education: The Future is All-Over (pp. 27-44). Cham: Palgrave Macmillan. https://doi.org/10.1007/ 978-3-030-73770-2_2.

Knochel, A. D. (2021). Post Scripts in the Present Future: Conjuring the Post-conditions of Digital Objects. In K. Tavin, G. Kolb, \& J. Tervo (Eds.), Post-Digital, Post-Internet Art and Education: The Future is All-Over (pp. 99-113). Cham: Palgrave Macmillan. https://doi.org/10.1007/ 978-3-030-73770-2_6.

Knox, J. (2016). Posthumanism and the Massive Open Online Course. Contaminating the Subject of Global Education. London: Routledge.

Kolb, G. (2021). Notes on Corpoliteracy: Bodies in Post-digital Educational Contexts. In K. Tavin, G. Kolb, \& J. Tervo (Eds.), Post-Digital, Post-Internet Art and Education: The Future is All-Over (pp. 167-182). Cham: Palgrave Macmillan. https://doi.org/10.1007/978-3-030-73770-2_10.

Kommoss, P. (2021). New Intimates. In K. Tavin, G. Kolb, \& J. Tervo (Eds.), Post-Digital, Post-Internet Art and Education: The Future is All-Over (pp. 147-165). Cham: Palgrave Macmillan. https://doi. org/10.1007/978-3-030-73770-2_9.

MacKenzie, A., Bacalja, A., Annamali, D., Panaretou, A., Girme, P., Cutajar, M., Abegglen, S., Evens, M., Neuhaus, F., Wilson, K., Psarikidou, K., Koole, M., Hrastinski, S., Sturm, S., Adachi, C., Schnaider, K., Bozkurt, A., Rapanta, C., Themelis, C., Thestrup, K., Gislev, T., Örtegren, A., Costello, C., Dishon, G., Hoechsmann, M., Bucio, J., Vadillo, G., Sánchez-Mendiola, M., Goetz, G., Gusso, H. L., Aldous Arantes, J., Kishore, P., Lodahl, M., Suoranta, J., Markauskaite, L., Mörtsell, S., O’Reilly, T., Reed, J., Bhatt, I., Brown, C., MacCallum, K., Ackermann, C., Alexander, C., Leah Payne, A., Bennett, R., Stone, C., Collier, A., Lohnes Watulak, S., Jandrić, P., Peters, M., \& Gourlay, L. (2021). Dissolving the Dichotomies Between Online and Campus-Based Teaching: a Collective 
Response to The Manifesto for Teaching Online (Bayne et al. 2020) (2021). Postdigital Science and Education. https://doi.org/10.1007/s42438-021-00259-z.

Mañero, J. (2020). Postdigital Brave New World and Its Educational Implications. Postdigital Science and Education, 2(3), 670-674. https://doi.org/10.1007/s42438-020-00129-0.

Meyer, T. (2021). A New Sujet/Subject for Art Education. In K. Tavin, G. Kolb, \& J. Tervo (Eds.), PostDigital, Post-Internet Art and Education: The Future is All-Over (pp. 131-145). Cham: Palgrave Macmillan. https://doi.org/10.1007/978-3-030-73770-2_8.

Rousseau, G., \& Sternfeld, N. (2021). Educating the Commons and Commoning Education: Thinking Radical Education with Radical Technology. In K. Tavin, G. Kolb, \& J. Tervo (Eds.), Post-Digital, Post-Internet Art and Education: The Future is All-Over (pp. 117-129). Cham: Palgrave Macmillan. https://doi.org/10.1007/978-3-030-73770-2_7.

Sweeny, R. W. (2021). Post-Internet Art and Pre-Internet Art Education. In K. Tavin, G. Kolb, \& J. Tervo (Eds.), Post-Digital, Post-Internet Art and Education: The Future is All-Over (pp. 45-59). Cham: Palgrave Macmillan. https://doi.org/10.1007/978-3-030-73770-2_3.

Schütze, K. (2021). Bodies of Images: Art Education After the Internet. In K. Tavin, G. Kolb, \& J. Tervo (Eds.), Post-Digital, Post-Internet Art and Education: The Future is All-Over (pp. 81-97). Cham: Palgrave Macmillan. https://doi.org/10.1007/978-3-030-73770-2_5.

Schmidt, H. (2021). What Is the Poor Image Rich in? In K. Tavin, G. Kolb, \& J. Tervo (Eds.), PostDigital, Post-Internet Art and Education: The Future is All-Over (pp. 183-201). Cham: Palgrave Macmillan. https://doi.org/10.1007/978-3-030-73770-2_12.

Steyerl, H. (2009). In defense of the poor image. $e$-flux, 10. https://www.e-flux.com/journal/10/61362/indefense-of-the-poor-image/. Accessed 14 December 2021.

Smith, T. J. (2021). Toward an Anti-Racist and Anti-Colonial Post-Internet Curriculum in Digital Art Education. In K. Tavin, G. Kolb, \& J. Tervo (Eds.), Post-Digital, Post-Internet Art and Education: The Future is All-Over (pp. 239-256). Cham: Palgrave Macmillan. https://doi.org/10.1007/978-3030-73770-2_14.

Tavin, K., Kolb, G., \& Tervo, J. (2021). Post-Digital, Post-Internet Art and Education: The Future is AllOver. Cham: Palgrave Macmillan.

Zahn, M. (2021). Aesthetic Practice as Critique: The Suspension of Judgment and the Invention of New Possibilities of Perception, Thinking, and Action. In K. Tavin, G. Kolb, \& J. Tervo (Eds.), PostDigital, Post-Internet Art and Education: The Future is All-Over (pp. 183-201). Cham: Palgrave Macmillan. https://doi.org/10.1007/978-3-030-73770-2_11.

Publisher's Note Springer Nature remains neutral with regard to jurisdictional claims in published maps and institutional affiliations. 